\title{
Biodiversity Conservation in Nigeria: Perception, Challenges and Possible Remedies
}

\author{
Anwadike BC* \\ National Open University of Nigeria/College of Education, Nigeria \\ *Corresponding author: Anwadike BC, National Open University of Nigeria/ College of Education, Warri, Nigeria
}

\begin{abstract}
There are rapid changes in worldwide species distribution and abundance especially in the tropics and subtropics where they occur in abundance relative to other regions of the world .Countries worldwide including Nigeria show strong inclination towards effective biodiversity monitoring to maintain and sustainably utilize their biological resources Nigeria is blessed with a plethora of biodiversity and biological resources including plants, animals and ecosystems to the extent that some of them are threatened to extinction and degradation resulting from the imbalance between economic development and biodiversity conservation. Some major threats to biodiversity conservation in Nigeria include poverty, economic development, incomplete or non implementation and non ratification by government of international treaties and conventions on conservation issues, ambiguous governmental laws on biodiversity, climate change, pollution, invasion by alien species etc. According to the IUCN Red list of 2013, Nigeria has a total of 309 threatened species in the following taxonomic categories: Mammals (26), Birds (19), Reptiles (8), Amphibians (13), Fishes (60), Mollusks (1), other Invertebrates (14) and Plants (168) Possible remedies include concerted effort towards the implementation and ratification of treaties and conventions on biodiversity, educating the populace to forgo cultural practices that are inimical to conservation of biological resources. The essence of this paper is to highlight some of these unwholesome practices that endanger biodiversity and to sensitize the populace on the importance of biodiversity conservation practices in Nigeria.
\end{abstract}

Keywords: Biodiversity; Conservation; Degradation; Threats; Remedies

\section{Introduction}

There are species abundance, diversity and distribution especially in the tropics and subtropics which are undergoing remarkable declining changes due to climate change, rapid economic development, over exploitation of natural resources and possibly social apathy towards conservation of biological resources. The need for biodiversity conservation cannot be over emphasized because of the role it plays in the socio economic lives of the people. Many countries of the world including Nigeria has began to show much inclination towards conservation practices to avoid imminent extinction of species and ecosystems. It is worthy of note that emanating from the circumstance above, many countries of the world have set up national monitoring activities and are earnestly looking forward to the global observation and science community for guidance and facilitation. Biodiversity globally is threatened mainly by climate change resulting in the disappearance of animal species and extinction of rare fruit and plant species. In Nigeria the conservation of biodiversity is very much fundamental to life and positive business performance especially in the oil and gas sector.
Unfortunately High Biodiversity Value Areas (HBVA) is allowed to be destroyed under different guise. It is worthy of mention that arising from the circumstance above many countries of the world have set up monitoring agencies and are effectively looking forward to the global observation and science community for guidance and facilitation No doubt that nature is endowed with a vast array of human, material, and biological resources that constitute life support system required to sustain and meet human needs. The resources constitutes time wealth required to create other wealth and thus needs to be carefully and adequately maintained, sustained and judiciously utilized so that tire present generation can meet their own needs without jeopardizing the ability of future generation to meet their arid thus a case of enhanced sustainable development.

Historically, Nigeria became a signatory to the Convention on Biodiversity (CBD) in 1994 committing her to the three objectives of the convention; conservation of biodiversity, sustainable use of its component and the fair and equitable sharing of resources 
arising from the effective use of genetic resources. The Nigerian environment is blessed with rich ecological potentials necessary for human development and transformation and is presently threatened with decline in quality and quantity at an alarming rate due to over exploitation and misuse. The environment provides a life support system and basic resources for all socio-economic activities, Natural and anthropogenic activities of man remain the major threats to these rich and exhaustible natural resources in particular and to the environment in general [1]. Possible causes of environmental degradation and possibly loss of biodiversity includes rapid population growth, overexploitation of natural resources, poverty, poor economic performance, weak institution and legal framework, poor agricultural practices and high dependence on biomass fuel among others [2]. The consequences are felt on the human population and globe environmental changes such as climate change; rise in sea level, desertification, draught, flooding, rainfall variation, green house effects, biodiversity loss, coastal and marine habitat destruction, fresh water contamination, land degradation air and water pollution and urbanization.

Biological diversity of biodiversity means the variety of plants and animals life all the ecosystem, community or species level, and even at the genetic level. Biodiversity was a word that first came and used in science lexicon in 1988. The concept was first defined at the 1992 United Nations Convention on Biodiversity as " the variability among living organisms from all sources including inter alia, terrestrial, marine and other aquatic ecosystems and the ecological complexes of which they are part: this includes diversity within species, between species and ecosystems [3]. Global species richness estimates the range of 3 million to 100 million species on earth and most occur in the tropical and subtropical regions of the world which encompass many of the world's conservation priority hot spots. Biodiversity is most measured and reported at species level with characteristics such as species richness, species diversity and uniqueness of species to certain areas [2]. The term is broad based and all encompassing to include both higher plant/ animals and other lower organisms which constitutes the focus of the conservation efforts.

According to [4], our rich terrestrial, aquatic/ marine biodiversity is threatened by unfavorable global climate change and there is remarkable disappearance of some plant and animal species rapidly tending towards extinction while [5] decried the much talk on biodiversity conservation in Nigeria without a commensurate action on implementation. He further remarked what he called "the circuit of talk -fest and exhibition of retail information and much recycled print or web based knowledge" on biodiversity conservation without commensurate positive action to actually address the humongous challenge. He observed that the national agenda for participation in the UN Convention on Biodiversity Conservation and Climate Change which Nigeria has always being a part of. , but asked where we are today? Today we are signatory to the Rio and other conventions with large delegations attending summits and other international conferences on threats to biodiversity and climate change which have fallen short of addressing the unprecedented biodiversity depletion and reckless deforestation in Nigeria. Nigeria has never lacked talk shows on threats to the environment especially on global biodiversity and climate change, rather in Sub Saharan Africa what is lacking is the affirmative action to be taken [6] remarked that there is social apathy to conservation, security, complexity and diversity of communities, conflicting interest and difficulties in the dissemination of the state of protected areas because of current abuse (airports and housing estates built inside protected areas).

From the foregoing it shows that biodiversity resources are very much under the threat of obvious extinction if the needful is not done to avert it, hence the need for the study. Nigeria is rich in biodiversity of plant and animal species attributable to complex topography, favorable climate and wide range of habitats. Nigeria has endemic flora of 91 species belonging to 44 families with the Rubiaceae family having the highest composition. According to the IUCN Red list 2013, Nigeria has a total of 309 threatened species in the following taxonomic categories: Mammals (26), Birds (19), Reptiles (8), Amphibians (13), Fishes (60), Mollusks (1), other Invertebrates (14) and Plants (168) (Sedghi, 2013). The categories of biodiversity related sites in Nigeria include: 7 National Parks of Old Oyo, Cross River, Gashaka-Gumti, Okomu, Chad Basin, Kainji Lake, and Kamuku; 27 Important Bird Areas including all National Parks and 60\% the Ramsar sites; 11 Ramsar Sites; 2 World Heritage Sites of Sukur Kingdom and Osun Osogbo Grove; 994 Forest Reserves; 32 Game Reserves; 1Biosphere Reserve; and many Sacred groves at varied level of protection.

\section{Threat to Biodiversity in Nigeria}

Biodiversity Nigeria is seriously under the threat of extinction from climate change, economic development, land use changes from agriculture, invasive species and pollution crude oil exploration and exploitation, canalization that has threatened mainly the mangroves, deforestation, desert encroachment, over hunting, land use, road and residential buildings construction etc. It is the fear of species extinction emanating from the poor attitude of both government and the citizenry towards the protection of biodiversity in Nigeria that has necessitated this work so that conservation practices should be implemented and taken seriously in the country to avoid a catastrophe of species extinction in the nearest future Africa and incidentally Nigeria have rich and varied biological resources forming its natural wealth in which its socio-economic system is based.Television2010 report on the state of the Nigerian environmental and other works and studies have described the nature and characteristics of the problems as discussed below $[2,7,8]$.

According to [2] natural habitats in Africa are being lost through anthropogenic activities of man, such as over harvesting of resources most notably timber and that mole than 21 million hectare of forest have been lost since 1970. Other threats to terrestrial habitat include bush fire especially in the savana, soil preparation for agriculture, over fishing, deforestation, roads, residential and commercial centres construction etc. In Nigeria there is desert encroachment and advancing south wards at an estimated rate $0.6 \mathrm{~km}$ a year with Borno, Jigawa, Katsina, Kebbi, 
Yobe and Sokoto greatly affected, with sokoto already loosing up to $11.43 \%$ of its total land area [7]. He also noted the problems of gully erosion in Agulu-Nanka of Anambra State and Imo state. [9] Stated that all the 36 states of Nigeria including Federal Capital Territory (FCT) are adversely affected by soil erosion. But the intensity and type vary from region to region. While wind erosion is common in the northern part of Nigeria where the soils are sandy, coastal erosion affect all the states bordering the Atlantic Ocean that includes; Ogun, Lagos, Ondo, Delta, Edo, Akwa Ibom, Rivers state, Bayelsa and Cross River state.

Nigeria has coastline of about $853 \mathrm{~km}$ long, with the coastal areas being the most populated zones but being most seriously threatened by coastal and marine erosions and land subsidence, Its devastating effects are found in the low lying belts of the mangrove and freshwater swamps along the coast and plains of large rivers in the coastal southern states of Nigeria [7, 10]. Nigeria is rated the 6thworld'slargest producer of crude oil with reserves running into billions of naira and large deposition of solid minerals and rich biodiversity; yet classified among the 2 poorest countries of the world [11]. Crude oil exploration and exploitation also created serious problems especially hi the Niger Delta, resulting to hazards such as soil degradation; deforestation, water resources degradation and destruction of biodiversity have caused huge losses in terms of human life, natural resources and infrastructural losses [7]. Estimate shows that 21.1 million hectares of African forest have been lost since 1970 accounting for about 30 percent of the original extent while land under cultivation has increased by 3 million hectares orover21 percent [2]. Anthropogenic activities that have resulted in the degradation of the forest include, clearing and burning of forest; over harvesting of plants anti animals ,indiscriminate use of persistent or recalcitrant chemical pesticides, draining and filling of wetlands, destructive fishing practices, air pollution and the conversion of protected lands for agricultural and urban development purposes. These activities are the result of population explosion and increasing poverty as well as economic policies and priorities. The Nigerian forest are rich in biodiversity and covers Edo, Ondo and Cross River states respectively and because of the vast resources that can be obtained from them ,they have been massively exploited for economic and development purposes.

Savannas which are the second dominant ecosystem in Nigeria second to the forest are equally exploited and depleted for food, fuel wood and other resources. The consequences have been the loss of vegetation cover, fertile topsoil and fauna species. Wildlife loss is equally threatened and the term encompasses all living organisms that exist in the wild state. Population and human pressure are implicated as being responsible for ecological imbalance resulting in habitat and species losses, genetic traits and associated ecological changes in wildlife population [10]. In Africa estimates shows that $201 \mathrm{~J}$ recorded animals species are threatened with 126 extinct while 1771 plants species recorded are threatened with over 123 extinct (WUN) and [2], One of the major threats which is widely overlooked is that there are too many governmental agencies on environmental protection and conservation. These agencies work at cross purposes thereby compounding their statutory functions e.g. forest guards connive with loggers to fell trees indiscriminately for pecuniary inducement.

\section{Environmental conservation practices in Nigeria}

The International, Union for the Conservation of Nature and Natural Resources (IUCN) defines conservation as the management of the human use of the biosphere so that it can yield the greatest sustainable benefit while maintaining its potential to meet the needs and aspiration of future generations. The history of conservation in Nigeria started from the colonial era with the establishment of forest resources. [10] noted that, the traditional methods of conserving natural resources among other methods include, creating forest reserve areas for relaxation and religion purposes, prohibiting collection of firewood from designated forested areas .The farming areas being separated from the protected forests. After independence in 1960 traditional natural regeneration practices were abandoned for monoculture plantation such as the growing of the teak plant known as Tectonia grand is in the west Gmelina arbrea and Elaieis guineensis in the east, Heveas brasihensis, Eucalypius sp and Pinus spp in most parts of Midwest and Eastern part of Nigeria. The Nigeria's forest reserves were managed and protected by states forest reserve while at the Federal level, the Federal Department of Forestay and Agriculture Land Resources in The Ministry of Agriculture and Natural Resources were responsible for conservation matters in Nigeria [1].

The Niger ran Conservation Foundation (NCF) was founded in 1980 and work with governmental and non-governmental organizations to conserve and protect the environment and consequently biodiversity. Some of the reputable partners are World Wide Fund for Nature (WWF), bird Life international Royal society for the Protection of birds (RSPB), World Conservation Union (WCU), federal ministries and other NGOs. Some of the NCF conservation projects include Okomu wetland, projects, NCF/international institute of Tropical Agricultural (UTA), Watershed Management Projects, review of the National Forestry Policy in 2002, the Mangrove Forest and Hadeja Wetland Project, Ecotourism etc. The NCF focuses on policy reforms, protected area management environmental education training and capacity building community participation, international cooperation, field research and inventory work and collaborative management programmes between Nigeria and Cameroun for sustainable cross border management of resources in Cross River in Nigeria/Karip Natural Park in Cameroon.

In Nigeria from table 1,there are 25 threatened mammals; 19 birds species, 2 reptiles species, 10 amphibians species, 2 fish species, 1 invertebrate, 119plant species and a total of 158 species that are threatened. Dril (lmandrillusleucophaeus) found in Central Africa and also in Cross River state of Nigeria and even Gorilla (Gorilla dretii) the Cross River Gorilla and still found in the bonier between Nigeria and Cameroon as well as the sub regional border between Western and Central Africa [12]. Other species 
are threatened by a few invasive species of plant and animals. The Nypapalm is threatening mangrove forest in coastal West Africa and tire bracken fern is encroaching on savanna ecosystem. Invasive plants such as these use up water and nutrient resources and thus deprive native species and reduce biodiversity. Other threatened species in West Africa in (Table 1).

Table 1: Threatened species in Western Africa, 2000.

\begin{tabular}{|c|c|c|c|c|c|c|c|c|}
\hline Country & Mammals & Birds & Reptiles & Amphibians & Fishes & Inverts & Plants & Total \\
\hline Benin & 7 & 2 & 1 & 0 & 0 & 0 & 11 & 21 \\
\hline Burkina Faso & 7 & 2 & 1 & 0 & 0 & 0 & 2 & 12 \\
\hline Cote d'Ivoire & 3 & 2 & 0 & 0 & 1 & 0 & 2 & 8 \\
\hline Cape Verde & 17 & 12 & 2 & 1 & 0 & 1 & 101 & 134 \\
\hline Gambia & 3 & 2 & 1 & 0 & 1 & 0 & 3 & 10 \\
\hline Ghana & 13 & 8 & 2 & 0 & 0 & 0 & 115 & 138 \\
\hline Guinea & 11 & 10 & 1 & 1 & 0 & 3 & 21 & 47 \\
\hline Guinea Bissau & 2 & 0 & 1 & 0 & 1 & 1 & 4 & 9 \\
\hline Liberia & 16 & 11 & 2 & 0 & 0 & 2 & 46 & 77 \\
\hline Mali & 13 & 4 & 1 & 0 & 1 & 0 & 6 & 25 \\
\hline Mauritania & 13 & 2 & 0 & 0 & 0 & 0 & 0 & 20 \\
\hline Niger & 11 & 3 & 0 & 0 & 0 & 1 & 2 & 17 \\
\hline Nigeria & 25 & 9 & 2 & 0 & 2 & 1 & 119 & 158 \\
\hline Senegal & 11 & 4 & 6 & 0 & 1 & 0 & 7 & 29 \\
\hline Sierra Leona & 11 & 10 & 3 & 0 & 0 & 4 & 43 & 71 \\
\hline Togo & 9 & 0 & 2 & 0 & 0 & 0 & 9 & 20 \\
\hline
\end{tabular}

West African countries including Nigeria have responded to the problems of habitat loss by placing natural areas under protection. However, the number and size of protected areas in West Africa vary from country to country as shown in (Table 2), in 1999, 13 urkina Faso and Senegal had over 10 percent of their land area under national protection whereas in Guinea and Guinea i3issau this was less than 1 percent although they do have marine protected areas [13]. While Nigeria can boast of only 27 nationally protected areas and some of the areas Include Obudu Plateau, Gashaka-Gumti in
Taraba, Chad basin National Park, Akassa Forest in Bayelsa state, as well as Aifi Forest in Cross River state NCF, 2002). (Table 3) shows the internationally protected areas in West Africa showing increased efforts to conserve natural habitats which have been very successful. This increased effort is attributed to the ratification of the Ramsar Convention and the Convention of Biodiversity. There are 15 Biosphere Reserves in the sub-region, 10 world Heritage sites and 37 Rassar sites. One of the Raznaar sites found in Nigeria is, the Omo Biosphere Reserve in Ogun state, Nigeria.

Table 2: Nationally protected areas in Western Africa.

\begin{tabular}{|c|c|c|c|c|}
\hline Country & Number & Terrestrial Area (000 ha) & 96 land area & Marine number \\
\hline Burkina Faso & 2 & 778 & 6.9 & 10.1 \\
\hline Cote d'Ivoire & 12 & 2855 & 6.2 & 2 \\
\hline Gambia & 11 & 1985 & 4.6 & 5 \\
\hline Ghana & 6 & 23 & 0.7 & 0 \\
\hline Guinea & 10 & 1104 & 1.2 & \\
\hline Guinea Bissau & 3 & 164 & 3.7 & \\
\hline Liberia & 0 & 0 & 1.7 & \\
\hline Mali & 1 & 129 & 7.7 & \\
\hline Mauritania & 9 & 4532 & 3.3 & \\
\hline Niger & 6 & 1746 & 11.1 & \\
\hline Nigeria & 27 & 3694 & 1.1 & \\
\hline Senegal & 12 & 2181 & & \\
\hline Sierra Leona & 2 & 82 & & 7 \\
\hline Togo & & & & \\
\hline
\end{tabular}




\begin{tabular}{|c|c|c|c|c|}
\hline Total & 9 & 429 & 76 & 1 \\
\hline & 123 & 28724 & 68.2 & 25 \\
\hline
\end{tabular}

Table 3: Internationally protected areas in Western Africa.

\begin{tabular}{|c|c|c|c|c|c|c|}
\hline \multirow{2}{*}{ Country } & \multicolumn{2}{|c|}{ Biosphere Reserves } & \multicolumn{2}{|c|}{ World Heritage Sites } & \multicolumn{2}{|c|}{ Ramsar Sites } \\
\hline & Numbers & Area (000 ha) & Numbers & Area (000 ha) & Numbers & Area (000 ha) \\
\hline Benin & 1 & 623 & 0 & 0 & 2 & 139 \\
\hline Burkina Faso & 1 & 186 & 0 & 0 & 3 & 299 \\
\hline Cote d'Ivoire & 2 & 1480 & 3 & 1504 & 1 & 19 \\
\hline Gambia & 0 & & 0 & 0 & 1 & 20 \\
\hline Ghana & 1 & 8 & 8 & 0 & 6 & 178 \\
\hline Guinea & 2 & 133 & 1 & 13 & 6 & 255 \\
\hline Guinea Bissau & 1 & 110 & 0 & 0 & 1 & 39 \\
\hline Liberia & 0 & & 0 & 0 & 0 & 0 \\
\hline Mali & 1 & 2349 & 1 & 400 & 3 & 162 \\
\hline Mauritania & 0 & & 1 & 1200 & 2 & 1231 \\
\hline Niger & 2 & 25128 & 2 & 7957 & 4 & 715 \\
\hline Nigeria & 1 & $<1$ & 0 & 0 & 1 & 58 \\
\hline Senegal & 3 & 1094 & 2 & 929 & 4 & 100 \\
\hline Sierra Leona & 0 & & 0 & 0 & 1 & 295 \\
\hline Togo & 0 & & 0 & 0 & 2 & 194 \\
\hline Total & 15 & 31111 & 10 & 12003 & 37 & 3674 \\
\hline
\end{tabular}

State of Environmental Treaties and Conventions

\section{in Nigeria}

Nigeria is a signatory to many global conventions, protocols and treaties which are relevant to environmental and Biodiversity conservation. [14] Noted that Nigeria has only ratified thirty global environmental conventions while leaving out fifty-two at the moment. She is equally affiliated to global institution, organization and agencies such as Global Environmental Facility GEF), UNDP, World Bank, World Conservation Union (WCU) etc. In 1992 Nigeria attended the Rio de Janeiro Conference on Sustainable Development and was a signatory to the Convention on Biodiversity. She took action immediately by initiating the preparation of a National Biodiversity Strategy and Action Plan. The goal of the plan is to conserve Nigeria's biodiversity and enhance its sustainable use by integrating biodiversity conservations into national planning policy and decision making process Emphasis is placed on biodiversity conservation within protected areas such as forest reserves and national parks and 37 gazette and proposed games reserves and sanctuaries exist in Nigeria. There is also the maintenance of a register of introduced species (about 53 alien plant species and 12 exotic animal species) [8]. It is worthy of mention that the GasthiaGumpti National Park in Nigeria encompass a range of habitat across a range of altitude from $450 \mathrm{~m}$ to $4,000 \mathrm{~m}$, chimpanzees are among the threatened species that survive in the forest. The Nigeria conservation Foundation (NCF) and WWF are developing a plan to promote tourism in the park, stimulating the economy through conservation efforts. The Drill rehabilitation and Breeding Centre
(DRBC) in Calabar, Nigeria was set up in cooperation with the Cross River State. Ministry of Agriculture, Forestry Department and Cross Rivers National Park, In May, 2000, the Afi Mountain Wildlife Sanctuary was gazette i.e. legally protected and will protect one of the Nigerian populations of the Cross River gorilla, as well as drills, chimpanzees and other private species (Gadaby and Jenkins, 1996) [12].

\section{Some major challenges to Conservation Practices in Nigeria}

a. There are many governmental agencies in charge of environmental matters that they work at cross purposes to the extent that statutory delineation is not adhered to. Such attitude may stem from corruption of some officials in agencies. Furthermore those charged with the responsibilities do no function properly probably because of obvious administrative bottlenecks and connivance between the operators and those flouting the order,

b. Conservation projects are seriously threatened by economic development that needs the areas for exploitation, mining, exploration, road expansion and highway networks [8]. Others are lack of conservation project sustainability, inadequate finance to fund projects, poverty among the local communities etc.

c. Paucity of trained man power and basic information on biodiversity

Conservation practices. 
d. National Legislation on Biodiversity is non existent

e. Threat of climate change

f. Incomplete knowledge of the species of organisms and their total worth is still unknown [15-17].

\section{Conclusion}

The importance of biodiversity as a natural resource cannot be over emphasized because of the basic needs they satisfy and their role as the vital cultural heritage of the nation, Therefore, there must be a conceited effort by the government and citizens to make wise use of these natural resources to avoid their degradation and depletion. Rapid population growth, over exploitation of resources, deepening poverty, weak institutional and legal framework need to be seriously addressed by integrating environmental and developmental objectives [18-20]. These problems need to be seriously addressed and mental education and transformation of its citizenry on the importance of biodiversity need to be given utmost attention. The essence of this is to balance up economic development and the environment since the former is the major threat to biodiversity conservation. Ratification of international convention and treaties and establishment regional action plans need to be supported with human and financial resources not just to comply with obligation but to implement activities and projects at the national and sub national levels [21-24].

\section{Recommendation}

a. Government should ratify the remaining convention and treaties in biodiversity conservation.

b. The implementation of the millennium development goal with emphasis on poverty reduction which will reverse the degradation of the environment water and sanitation by 2015 .

c. Poverty reduction through the application of modem agricultural practices such as taungya farming alley cropping, agro pastoral, improved fish farming and possible wildlife domestication.

\section{References}

1. Gasu M, Fadare O, Oiawale O (2005) Environment: Problems, challenges and remedies.

2. United Nations Environmental Program (2002) Africa Environment out Look Past, Present and Future Perspective, Earth Print Ltd, England.

3. Juan Antonio Herrera Izaguirre (1992) United Nations Convention on Biological Diversity.

4. Akpabio K (2016) "Keynote Address" Biodiversity Conservation and Challenges of Climate Change Workshop held at the University of Uyo, Nigeria.

5. Amakiri, J (2016) Environmental Management: Biodiversity Conservation and Sustainable Development. A paper delivered in a
Workshop on Biodiversity Conservation and Challenges of Climate Change, held at the University of Uyo, Nigeria.

6. Shell Petroleum Development Company (2016) The State of our Legislation on Biodiversity Conservation. A paper delivered in a Workshop on Biodiversity Conservation and Challenges of Climate Change, held at the University of Uyo, Nigeria.

7. Nwaehukwu J (2000) Nigeria Environment in the 20th Century, NCF 20th Anniversary Public Lecture Series No: 2, Nigeria Conservation Foundation, Nigeria.

8. Daura AS (2000) "Keynote address" Nigeria Conservation Foundation (NCF) $20^{\text {th }}$ Anniversary Public Lecture Series No: 2. NCF, Nigeria.

9. Aghede, Duitiah (2004) Causes and prevention of erosion in urban centers: A case of Okettunu/Sango Area of Ibadan city, Nigeria. International Journal of Environmental Issues 2(1\&2): 60-65.

10. Nigeria Environmental Study Team (1991) “Nigeria's threatened environment". A National profile, Intest Printers Ltd, Ibadan, Nigeria.

11. Lecture Okali DU (2004) J3modIversity and Poverty Alleviation being \&U. Edi: Memorial Lectures, Nigeria Conservation Foundation, Nigeria.

12. Quates (2001) Cross River Gorilla Workshop Oiyx 35(3): 263-266.

13. World Bank (2000) World Development Report. The World Bank, Washington DC, USA.

14. Atsegbua L, Akpotaire, Dinmowe (2003) Environmental Law in Nigeria Theory and Practice Ababa Press Ltd, Ethiopia, p: 78.

15. Adebayo RA, Uyi NO (2010) Biological control of invasive weed species: Nigerian experience. International Journal of Agricultural Research 5(12): 1100-1106.

16. Akagu R, Adeleke A (2012) Current status and threats facing the Nigeria vultures. Submitted to the pan-African Vulture Summit, Masai Mara, Kenya 16-20, April 2012. Nigerian Conservation Foundation, Nigeria.

17. Bioresearches Development Conservation Program (2015) Ogbogolo Community Biodiversity Action Plan (A GEF-UNDP Pilot Project in Rivers State), GEF-UNDP Niger Delta Biodiversity Conservation Project. Final Report by Bioresearches Development and Conservation Programme, Nigeria.

18. Bioresearches Development Conservation Program (2015) BDCP 2012. Restoration and the Conjunctive Sustainable Management of Native Mangroves and Nypa Palms in the Cross river Estuary of Nigeria (UNIDO GEF/BDCP/FMEnvt).

19. Gastron KJ (2010) Biodiversity in Sodhin, Enrich-PR Editors. Conservation Biology for all, Oxford University Press, United Kingdom.

20. Nigeria Conservation Foundation (2002) Nigeria Conservation Foundation Annual Report Nigerian Conservation Foundation (NCF), Nigeria.

21. United Nations Environmental Programme (UNEP, 2002) Africa Environment out Look past, present and future perspective. Earth Print Ltd, England.

22. Wilson EO (1988) Biodiversity. National Academy Press, USA.

23. Cambridge (2000) Global Biodiversity. World Conservation Press, England.

24. Earth's living Resources in $2^{1 \text { st }}$ century by Common Bridge and Jenkins. 
(c) $(9$

This work is licensed under Creative

Commons Attribution 4.0 License

To Submit Your Article Click Here: Submit Article

DOI: 10.32474/CIACR.2020.08.000293

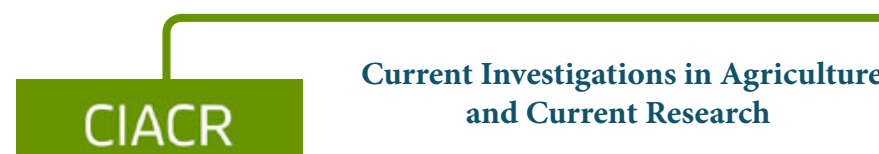

Assets of Publishing with us

- Global archiving of articles

- Immediate, unrestricted online access

- Rigorous Peer Review Process

- Authors Retain Copyrights

- Unique DOI for all articles 